\title{
Eksplorasi Etnomatematika pada Batik Pamiluto Gresik
}

\author{
Roisatun Nisa' \\ Prodi Pendidikan Matematika, Universitas Qomaruddin Gresik, Indonesia \\ Email: roisatunnisa@uqgresik.ac.id
}

\section{Tersedia Online di \\ http://www.jurnal.unublitar.ac.id/ index.php/briliant}

\begin{tabular}{l}
\hline Sejarah Artikel \\
\hline Diterima pada 24 April 2020 \\
Disetujui pada 26 Agustus 2020 \\
Dipublikasikan pada 31 Agustus \\
2020 Hal. 442-448 \\
\hline
\end{tabular}

\section{Kata Kunci:}

Etnomatematika; Batik Pamiluto Gresik

\section{DOI:}

http://dx.doi.org/10.28926/briliant .v3i4.462

\begin{abstract}
Abstrak: Penelitian ini bertujuan untuk untuk mendeskripsikan konsep-konsep matematika pada batik Pamiluto Gresik dan bagaimana pemanfaatan nilai-nilai budaya bangsa dapat diintegrasikan dalam pembelajaran matematika. Penelitian ini merupakan penelitian deskriptif dengan pendekatan etnografi dengan melaksanakan observasi dan wawancara kepada pengrajin batik dan kemudian dilakukan studi literatur terkait dengan geometrinya. Hasil penelitian pada batik Pamiluto Gresik adalah konsep-konsep titik, garis lurus, persegipanjang, lingkaran, belahketupat, trapesium, segitiga, dan simetri. Konsep yang terdapat pada Batik Pamiluto Gresik dapat dimanfaatkan sebagai media pembelajaran matematika melalui budaya lokal pada materi geometri.
\end{abstract}

\section{PENDAHULUAN}

Matematika merupakan salah satu ilmu pengetahuan yang selalu melekat dalam diri manusia. Disadari ataupun tidak, masyarakat dalam menyelesaikan permasalahan yang ada dalam hidupnya, kadangkala telah dan akan menggunakan matematika. Masyarakat dalam daerah tertentu khususnya daerah Gresik, yang tetap kental dalam mempertahankan kebudayaan, apabila dilihat dan diteliti, banyak hal-hal yang mengandung unsur-unsur matematis dalam setiap konteks kegiatan budaya yang dilakukan (Mustika, 2013).

Sebagai bangsa yang dilahirkan di tanah air Indonesia, kita wajib menjaga kelestarian budaya, salah satu budaya yang harus kita lestarikan adalah batik. Batik merupakan suatu warisan budaya yang mengandung unsur nilai kearifan suatu daerah, tapi adakalanya batik ini terabaikan seiring dengan kemajuan teknologi dan revolusi industry 4.0. Peranan batik ini akan menjadi sesuatu yang penting apabila kita sebagai bangsa Indonesia sering mengadakan beberapa kegiatan yang menyangkut terkait kebudayaan daerah serta mengadakan pameran batik dalam event-event tertentu (Pramono, 2013).

Pada tanggal 31 Januari 2017, Pemerintah kabupaten Gresik mematenkan batik Pamiluto menjadi batik khas Gresik setelah diterbitkannya hak paten dari Kementerian Hukum dan HAM RI Nomor D002017004963, Desain Batik Pamiluto Gresik yang dijadikan sebagai symbol khas kota pudak ini diantaranya adalah gambar gapura makam Sunan Giri dan Sunan Gresik, Pabrik, dan damar kurung. Gambar-gambar tersebut digabung dengan berbagai motif batik yang sudah ada sebelumnya (Romadhoni, 2017). Motif-motif yang ada dalam batik pamiluto ini 
menunjukkan beragam konsep matematika terutama konsep-konsep geometri. Hal tersebut secara tidak langsung bahwasanya konsep geometri tertanam pada masyarakat Gresik. Sehingga, jika terjadi perpaduan antara budaya, matematika, dan pendidikan maka akan melahirkan Ethnomathematics.

Etnomathematics dalam Bahasa Indonesia dikenal dengan istilah etnomatematika. Etnomatematika merupakan pembelajaran terkait gagasan atau ide matematika dari masyarakat terdahulu (Ascher, 1991). Etnomatematika diperkenalkan oleh D'Ambrosio, seorang matematikawan Brasil pada tahun 1977. Ethnomatematika memiliki pengertian yang lebih luas dari hanya sekedar ethno (etnik) maka etnomatematika diartikan sebagai antropology budaya dari matematika dan pendidikan matematika (Arwanto, 2017).

Melalui gagasan etnomatematika, masyarakat bisa memperkaya pengetahuannya terkait matematika yang ada di sekitarnya. Sehingga, apabila masyarakat banyak yang mengkaji etnomatematika, maka pembelajaran matematika akan lebih bermakna dengan dengan mengambil budaya setempat (Huda, 2018). Tuntutan kurikulum dan target kompetensi dasar yang harus dipenuhi oleh guru pada saat ini yang menyebabkan pembelajaran matematika menjadi kurang bermakna, hal ini terlihat bahwa pemahaman konsep matematika masih sangat kurang dan siswa seringkali tidak mengenal budaya setempat yang sekiranya dapat diaplikasikan dalam pembelajaran matematika. Dengan adanya batik Pamiluto, siswa akan lebih mudah mengenal konsep geometri dari beberapa budaya sekitar yang terdapat pada motif batik Pamiluto Gresik. Karena melalui motif gapura makam Sunan Giri dan Sunan Gresik, Pabrik, dan damar kurung menjadikan batik menjadi salah satu media dalam pembelajaran geometri melalui budaya lokal.

Melalui penelitian ini diharapkan pengetahuan tentang matematika tidak hanya pada pendidikan formal saja tetapi pembelajaran yang menekankan pada aspek sosial budaya masyarakat sekitar. Sehingga nilai-nilai budaya lokal dapat diintegrasikan dalam pembelajaran matematika, seperti halnya dapat diintegrasikan pada batik pamiluto Gresik.

Berdasarkan latar belakang yang telah diuraikan diatas, maka penulis melakukan penelitian dengan mengambil batik sebagai bahan penelitian. Sehingga penulis mengadakan penelitian yang berjudul "Eksplorasi Etnomatematika pada Batik Pamiluto Gresik".

\section{METODE}

Penelitian ini merupakan penelitian deskriptif dengan pendekatan etnografi yaitu pendekatan empiris dan teoritis yang bertujuan mendapatkan deskripsi dan analisis unsur kebudayaan masyarakat atau suku bangsa. Pendekatan ini memusatkan usaha untuk menemukan, bagaimana guru atau calon guru matematika, anak-anak atau masyarakat mampu mengorganisasikan budaya sekitar mereka dalam pikiran mereka dan mampu menerapkan ke dalam proses pembelajaran matematika.

Sehubungan dengan pelaksanaan penelitian ini, peneliti menggali beberapa informasi dengan melaksanakan observasi dan wawancara dengan narasumber selaku pengrajin batik dan dua karyawan untuk mengetahui informasi mengenai konsep geometri dalam pembuatan batik pamiluto. Dalam pemilihan subjek, pengrajin batik dan dua karyawan yang dipilih adalah subjek yang komunikatif. Tiga subjek tersebut sebagai narasumber untuk mengecek kredibilitas data terkait 
konsep geometri dalam pembuatan batik Pamiluto Gresik. Pengumpulan data dilakukan dengan melaksanakan wawancara kepada seseorang yang paham terhadap situasi obyek penelitian. Kemudian data dianalisis dengan membuat transkrip hasil wawancara.

Hasil transkrip yang diperoleh, kemudian direduksi. Peneliti membuat reduksi data dengan cara memilah semua data yang sesuai dengan kebutuhan peneliti, kemudian menghapus data yang tidak sesuai dengan kebutuhan peneliti. Selanjutnya data akan disajikan baru kemudian dianalisis dan disimpulkan. Kesimpulan ini merupakan dari hasil jawaban terhadap pertanyaan penelitian yang diteliti.

\section{HASIL}

Hasil dari Penelitian ini berupa deskripsi dari beberapa ikon khas Gresik pada batik pamiluto Gresik yang mengandung nilai-nilai Matematis. Beberapa motif yang ada pada batik Pamiluto Gresik ini menggandung beberapa konsep matematika Konsep-konsep Matematika tersebut antara lain konsep bangun datar dan, simetri. Pengrajin batik Pamiluto Gresik ini secara tidak langsung telah menanamkan nilai-nilai matematis pada setiap motifnya. Adapun kajian mengenai konsep-konsep matematika pada motif batik pamiluto ini dapat dideskripsikan sebagai berikut.

\section{Konsep Bangun Datar pada Motif Batik Pamiluto Gresik}

Konsep bangun datar yang dimaksud dalam penelitian ini adalah bangun datar segitiga, segiempat dan lingkaran
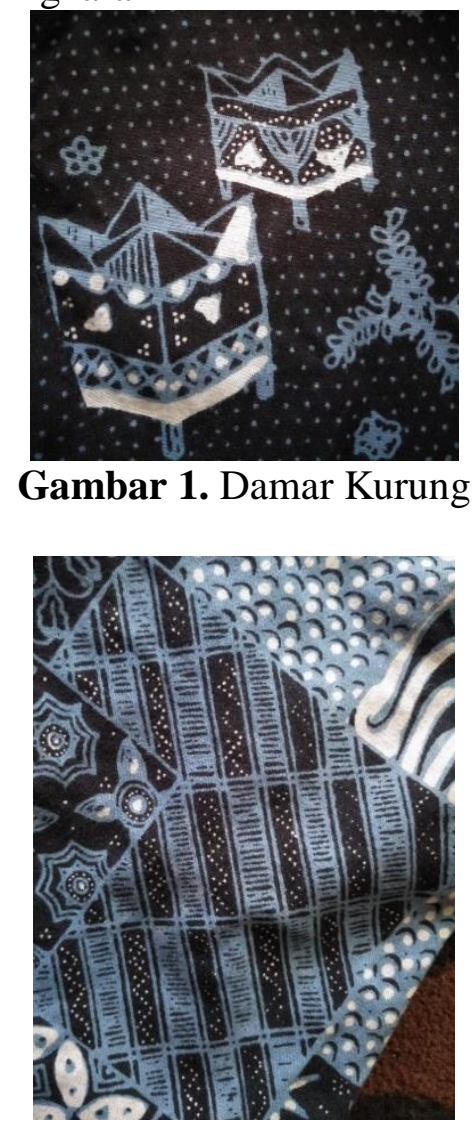

Gambar 2. Motif Persegipanjang dan Garis 


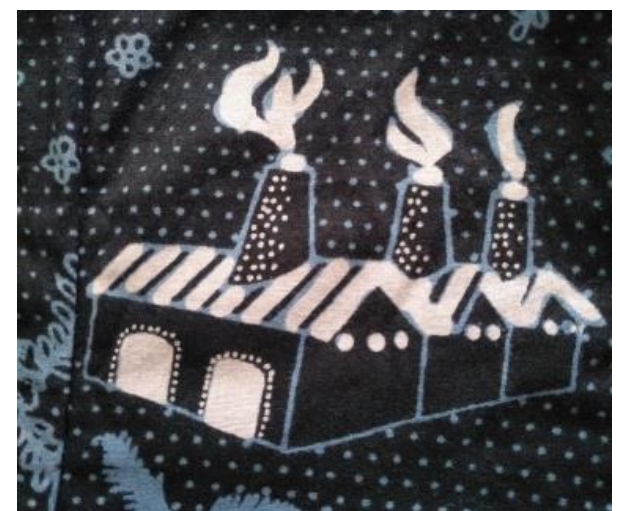

Gambar 3. Pabrik

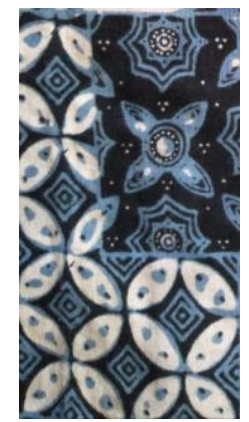

Gambar 4. Motif Kawung

Berdasarkan hasil wawancara dengan pengrajin batik tentang gambar di atas, pada gambar 1. terdapat motif damar kurung yang mana damar kurung memiliki karakteristik geometri. Diantaranya: berbentuk kubus, memiliki hiasan atas berbentuk segitiga sama sisi atau segitiga siku-siku yang membentuk huruf "M" pada atas lentera, terdapat bentuk belah ketupat yang menghiasi damar kurung. Pada gambar 2. Terdapat motif titik, garis, dan persegi panjang. Pada gambar 3. Batik pamiluto memiliki motif pabrik. Hal tersebut mengindikasikan bahwa Gresik merupakan kota industri. Hal yang terkait dalam pembelajaran geometri adalah bagian depan atau belakang bagian atas dinding pabrik berbentuk segitiga dan bentuk lingkaran. Pada gambar 4. terdapat motif kawung yang berbentuk lingkaran dan belah ketupat.

\section{Konsep Simetri pada Motif Batik Pamiluto Gresik}

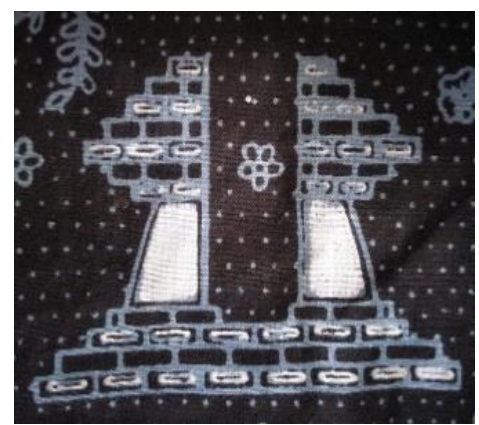

Gambar 5. Gapura Makam Sunan Maulana Malik Ibrahim 


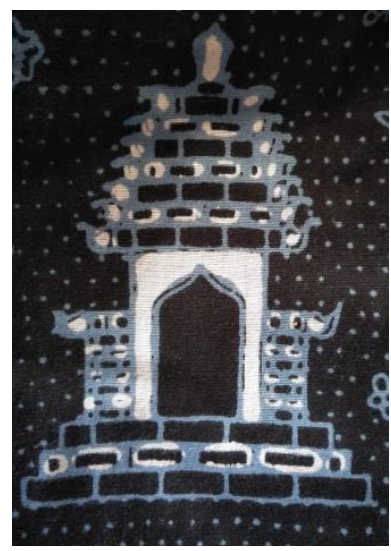

Gambar 6. Gapura Makam Sunan Giri

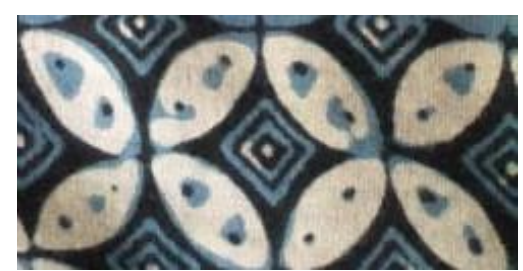

Gambar 7. Motif Kawung

Pada beberapa gambar di atas yang terdapat pada motif batik pamiluto Gresik, terdapat konsep simetri. Dalam hal ini yang dimaksud adalah simetri lipat. Hasil observasi dan wawancara menunjukkan bahwa Pada gambar 5. dan gambar 6. terdapat gapuro makam sunan Giri dan Gapuro makam Sunan Maulana malik Ibrahim menunjukkan sejarah Islam Walisongo yang masuk ke kota Gresik. Dan sampai saat ini dua sunan tersebut tidak pernah sepi pengunjung. Kedua Gapura menunjukkan adanya konsep simetri lipat. Pada gambar 7. Pada motif kawung juga menandakan adanya simetri lipat pada setiap motif tersebut. Hal ini mengindikasikan bahwa konsep simetri pada batik pamiluto mengandung unsurunsur nilai budaya yang dapat diimplementasikan dalam pembelajaran matematika khususnya peserta didik yang berdomisili di Gresik.

Secara garis besar, konsep matematika pada batik pamiluto Gresik dapat dilihat pada tabel di bawah ini.

Tabel 1. Hasil Peta Konsep Matematika pada Batik Pamiluto Gresik

\begin{tabular}{|c|c|c|}
\hline No. & Konsep Geometri & Batik \\
\hline 1. & $\begin{array}{ll}\text { - } & \text { Segitiga } \\
\text { - } & \text { Belah ketupat } \\
\text { - } & \text { Garis Lurus }\end{array}$ & $\begin{array}{l}\text { Gambar 1. Damar } \\
\text { Kurung }\end{array}$ \\
\hline 2. & $\begin{array}{ll}\text { - } & \text { Persegi } \\
& \text { panjang } \\
\text { - } & \text { Lingkaran } \\
\text { - } & \text { Titik } \\
\text { - } & \text { Garis lurus }\end{array}$ & $\begin{array}{l}\text { Gambar 2. Motif } \\
\text { Persegi panjang dan } \\
\text { garis }\end{array}$ \\
\hline 3. & $\begin{array}{ll}\text { - } & \text { Segitiga } \\
\text { - } & \text { Titik } \\
\text { - } & \text { Garis lengkung }\end{array}$ & Gambar 3. Pabrik \\
\hline
\end{tabular}




\begin{tabular}{|c|c|c|}
\hline No. & Konsep Geometri & Batik \\
\hline 4. & $\begin{array}{ll}\text { - } & \text { Lingkaran } \\
\text { - } & \text { Belah ketupat }\end{array}$ & $\begin{array}{ll}\text { Gambar } & 4 . \\
\text { Lingkaran }\end{array}$ \\
\hline 5. & $\begin{array}{ll}\text { - } & \text { Simetri } \\
\text { - } & \text { Persegi } \\
& \text { panjang } \\
\text { - } & \text { Trapesium } \\
\text { - } & \text { Titik }\end{array}$ & 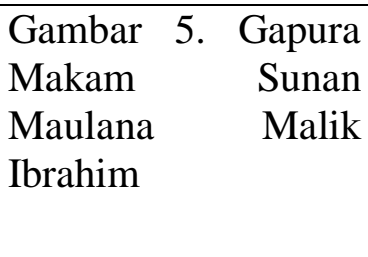 \\
\hline 6. & $\begin{array}{ll} & \text { Simetri } \\
\text { - } & \text { Persegi } \\
& \text { panjang } \\
\text { - } & \text { Titik }\end{array}$ & $\begin{array}{l}\text { Gambar } 6 \text { Gapura } \\
\text { Makam Sunan Giri }\end{array}$ \\
\hline 7. & $\begin{array}{ll}\text { - } & \text { Simetri } \\
\text { - } & \text { Lingkaran } \\
\text { - } & \text { Belah ketupat }\end{array}$ & $\begin{array}{lll}\text { Gambar } & 7 . & \text { Motif } \\
\text { Kawung } & & \end{array}$ \\
\hline
\end{tabular}

\section{PEMBAHASAN}

Dari hasil penelitian yang telah dilakukan, terdapat beberapa konsep bangun datar pada Batik Pamiluto Gresik yakni konsep segitiga, persegi panjang, lingkaran, belah ketupat, dan trapesium. Pemahaman terkait konsep bangun datar yang dikaitkan dengan budaya sekitar akan meningkatkan pemahaman siswa sehingga pembelajaran akan lebih bermakna. Hal ini sesuai dengan pendapat Fitroh yang menyatakan bahwa pada Kurikulum 2013 menuntut untuk lebih mengenal budaya sebagai dasar peningkatan kemampuan pemahaman siswa terhadap budaya yang ada di sekitarnya (Fitroh, 2015).

Konsep simetri pada Batik Pamiluto Gresik ini bisa digunakan sebagai media pembelajaran matematika, dalam hal ini adalah simetri lipat. Siswa dapat memetakan konsep simetri lipat dari beberapa gambar pada motif Batik Pamiluto Gresik. Motif batik yang bisa digunakan sebagai pemahaman konsep simetri lipat diantaranya adalah gambar Gapuro makam Sunan Giri dan Sunan Maulana Malik Ibrahim. Hal ini sejalan dengan Wanita yaang menyatakan bahwa konsep simetri lipat penting dipahami dalam geometri sehingga siswa dapat memenfaatkan motif batik di lingkungan sekitar sebagai media pembelajaran (Wanita, 2014).

\section{KESIMPULAN}

Berdasarkan hasil penelitian di atas, maka dapat disimpulkan bahwa: Konsep-konsep matematika yang terdapat pada Batik Pamiluto Gresik adalah: titik, garis, segitiga, persegi panjang, lingkaran, belah ketupat, trapesium, dan simetri. Konsep yang terdapat pada Batik Pamiluto Gresik dapat dimanfaatkan sebagai salah satu media pembelajaran matematika melalui budaya lokal. Dengan demikian pembelajaran matematika siswa khususnya wilayah Gresik akan lebih bermakna karena terdapat dalam lingkungan budaya mereka sendiri.

\section{SARAN}

Beberapa saran yang dapat peneliti sampaikan bahwasanya etnomatematika yang ada pada lingkungan sekitar masih banyak yang perlu dikaji, tidak hanya batik saja, namun kebudayaan yang melekat pada daerah sekitar bisa digunakan sebagai 
media dalam proses pembelajaran sehingga pengetahuan akan terbangun dengan sendirinya dalam pemikiran siswa karena konsep itu akan muncul dari budaya mereka sendiri. Sehingga untuk peneliti selanjutnya diharapkan bisa mengesplorasi etnomatematika selain Batik Pamiluto Gresik.

\section{DAFTAR RUJUKAN}

Arwanto. (2017). Eksplorasi Etnomatematika Batik Trusmi Cirebon Untuk Mengungkap Nilai Filosofi dan Konsep Matematis. Phenomenon, Jurnal Pendidikan MIPA.

Ascher, M. (1991). Ethnomathematics: A Multicultural View of Mathematical Ideas. California: Pasific Grove.

Fitroh, W. (2015). Identifikasi Pembelajaran Matematika dalam Tradisi Melemang di Kabupaten Kerinci Provinsi jambi. Prosiding Seminar Nasional Matematika dan Pendidikan UMS. Surakarta: UMS Surakarta.

Huda, T. N. (2018). Etnomatematika Pada Bentuk Jajanan Pasar di Daerah Istimewa Yogyakarta. JNPM (Jurnal Nasiona Pendidikan Matematikal), 217.

Mustika, R. G. (2013). Study Etnomathematics pada Permainan Keneker Masyarakat Adat Baduy. Bandung: Universitas Pendidikan Indonesia.

Pramono, K. (2013). Nilai Kearifan Lokal dalam Batik Tradisional Kawung. Jurnal Filsafat.

Romadhoni, M. (2017, February 24). Ini Filosofi Batik Pamilunto yang Asli Gresik. Surabaya, Jawa Timur, Indonesia.

Wanita, T. (2014). Developing the notion of symmetry through batik exploration. Surabaya: Universitas Negeri Surabaya. 